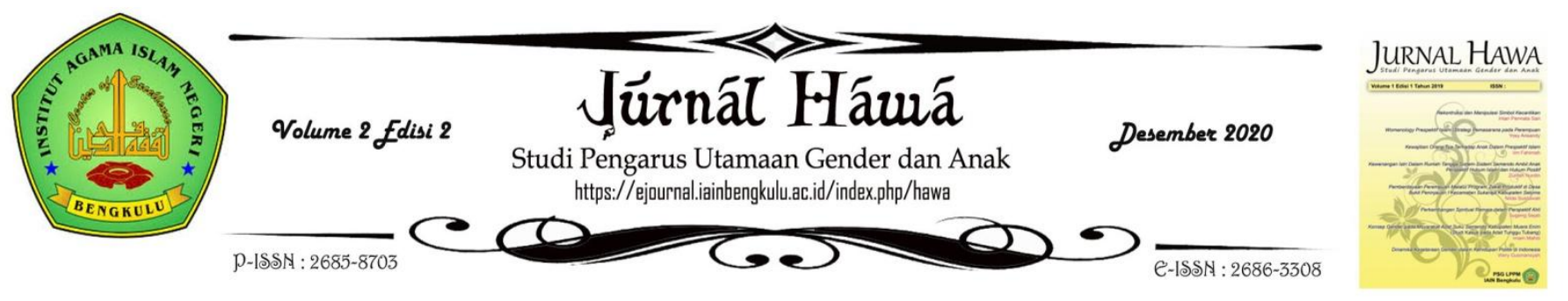

\title{
Feminine Stereotypes, Edueating Women Trough Literature: An Analysis of Guy de Maupassant Short Stories
}

\author{
Rany Syafrina \\ Sekolah Tinggi Bahasa Asing H. Agus Salim \\ ranisyafrina@gmail.com
}

\section{Info Artikel}

Diterima: Agustus 2020

Disetujui: September

2020

Dipublikasikan:

Desember 2020

\section{Keyword}

\section{Guy De}

Maupassant,

Short Stories,

Stereotypes

\section{Kata Kunei}

Guy De Maupassant, Cerita Pendek, Stereotip

\section{Abstract}

Guy de Maupassant is a French author whose works have been translated into English. Some of his shorts stories focused on women as the center of the story in which women become the source of misfortune as presented in five chosen short stories for this research. This research is part of objective approach research that focuses on analyzing literary works as it is, without considering the relationship of the intrinsic aspects to the reality of the world. Although the possible intention of the author to use literary work as a tool to educate readers is also explained. In delivering his ideas, Guy de Maupassant often describes women in stereotypes that include formlessness, instability, irrationality, piety, spirituality, materialism. Guy de Maupassant also used his literary work as an instrument to teach the readers about the concept of ideal women by providing advice if not criticism and humiliation; because trough reading literature, the knowledge transfer activities become possible.

\section{đbstrak}

Guyd De Maupassant merupakan penulis kesusatraan Prancis, karyanya telah banyak diterjemahkan dalam bahasa Inggris. Pada penelitian ini, telah dipilih lima cerita pendek yang ditulis oleh Guy De Maupassant dimana dalam cerita tersebut plot terpusat pada karakter utama wanita yang telah menikah namun kehadirannya dalam keluarga hanya menimbulkan kesengsaraan. Penelitian ini merupakan penelitian sastra yang bersifat objek, sehingga fokus utama penelitian ini terpusat pada unsur intrinsik karya meskipun nanti akan dibahas mengenai peranan karyasastra sebagai alat untuk menyampaikan ideologi. Dalam kelima karyanya, Guy De Maupassant menghadirkan wanita sebagai subjek yang lemah, tidak stabil dan rasional, sholeh, memiliki sifat spiritual namun materialistis. Guyd de Maupassant menggunakan karya sastra nya sebagai alat edukasi bagi pembacanya mengenai bagaimana perempuan harus bersikap dengan memberikan nasehat, kritik atau dengan mengolok-olok. Karya satra tidak hanya sebagai objek seni tetapi juga alat edukasi, karena dengan membaca karya sastra akan mendukung terjadinya transfer ilmu. 


\section{Introduction}

The stereotypes of women present in our reality, Eakins \& Eakins believe that stereotypes come from overgeneralization concepts that separate men and women in which both of them opposite each other if women intuitive and emotional then men are logical, realistic, assertive and competitive. If men are capable of doing science then women are unable to master them because they are created to be incapable of understanding science. Most of the time, the characteristic of male is more favorable than women because they are superior than the feminine traits (qtd in Sugino.1998).

The negative representation of women is also implemented into the real world as their discourse about women as marginal class remains practiced in our current life. Even in modern days, women are still seen as property in some parts of the world (Kathlyn and Gay Hendricks,2012) that makes them unable to make their own decisions regarding their own bodies. Historically, seeing woman as a property comes from an understanding that a daughter belongs to their father and family then later she belong to their husband as a wife. However, although time has passed while technology and knowledge have progressed massively, the traditional concept of women is still practiced within society.

The stereotypes of women have transformed into more complicated ideas that are not only classified by gender but also by age, race, ethnicity, and religion. Moreover, these stereotypes are not only accepted in our social life but also implemented and taught on work of art.
Women in classic literature are represented trough various ways, in women writing in which women become the main characters often represented as subjects who try to find their own happiness through love as written by classic author such as Jane Austen (Zirker. A. 2010), later women try to explore more opportunities in writing. They began to write about their female characters who fight for equal rights (Trombettea, 2016). Another variation of women's writings is the story about third world women who are not only marginalized trough their sex but also trough their race.

While women try to empower their female readers' trough writing, opposite approaches usually occur in some classic literature by male authors. In male-dominated authors, women often represent as weak and unable to make their own decision. Men are often depicted as more powerful and intelligent than women due to their physical difference and role in society: and in order to present male characters as superior, the author usually described women as marginalized in form of stereotypes.

Trough literary writing, men and women are not only distinguished by physical characteristics but also trough cultural values as well as discourse around them. Trough differentiation, women and men tend to share different care-taking role that makes each of them focus on specific purpose within the community. The differentiation between men and women can be possible trough stereotyping, as stereotyping allow us to create specific information about certain object. The most general understanding concept about stereotypes that it is" 
generally forms a very strong and powerful filter through which we process objective information about men and women" (Fiske and Taylor qtd in Ellemers 2018). It can also be said that stereotypes present to give us an impression about someone even if we only know limited information regarding the person.

Gender stereotyping is often present in classic literature because literature is not only seen as an object to be enjoyed as it is but it is also an instrument to educate the readers. As it is said by Pellegrino that literature is a powerful tool for teaching empathy and instilling drama in the teaching-learning encounter (qtd in Kautzmann, 1992). the presence of gender stereotypes in classic literature is to differentiate the characters between male and female as well as to give each of the different roles on their social function.

Trough reading classic literature, Marry Ellmann comes up with feminine stereotypes which often present in literature, these stereotypes of women in literature has purpose to determine the nature of women. She classified ten stereotypes of women that are often present in literary works including formlessness, passivity, instability, confinement, piety, materialist, spirituality, irrationality, compliance, and two incorrigible figures including the shrew and the witch. Each of them represents specific characteristic of women that has function to give general understanding about the nature of women based on male perspectives.

Ellmann describes that formlessness in women nature comes from the idea that women are less resistant than men because of their lack in both physic and mind, the formlessness on women leads to their passivity in which they are restricted to participate in social life. Moreover, women are also confined due to their limited experience. Women are also both unstable and irrational in which they show abnormalities although they are sane. (Ellmann, 1979).

Most women are described as materialist as they enjoy the luxurious item the most, Ellmann write that women description as materialist as they can be easily persuaded with material things such as clothing, appliance, and furnishing. In addition, women are both piety and spiritual; although the piety is only to display, they never feel it. While the spirituality on women is seen as premarital while they became extremely wild as Ellmann refer it to an alternate of hypersexuality. (Ellmann, 1979).

Stereotype on women does not only limited to Marry Ellmann classification of feminine stereotypes, some of the stereotypes toward women are not written by Ellman but present in real life. there are also stereotypes that specifically built for women who are minority to society. These stereotypes build general understanding of women characters. The nature of stereotypes does not give an objective point of view of certain community, often the stereotypes are build to maintain the patriarchy discourse within the society.

These stereotypes of women often present in classic literature as in Guy de Maupassant's short stories. Trough his short stories, he often placed women as the center of the story. However, 
women often bring out misery to the family and people around her. This paper tries to find out the type of feminine stereotypes that often present in Guy de Maupassant's short stories, and later unveil the purpose of his writing where the women are seen as the center of misery.

\section{Method}

This research is part of literary analysis research in which the data are taken from selected literary works and analyze them by using appropriate literary theory. For this research, 5 short stories from Guy de Maupassant are selected based on the status of the female characters on the story as the main characters. Since main character allows us to see a clear perspective of author toward women position at his time, as adding women as the main characters on his short stories allow him to explore the character's nature, it also makes him possible to treat the main female characters as the representation of women in general. The short stories that are included in this research are; The Kiss, The Diamond Necklace, The Umbrella, A Family Affair, and Dead Woman Secret in which all main female characters in the stories had married although some of them remained as widows.

Marry Ellmann concept of feminine stereotypes will be the basic concept that will be used for this research. Ellmann has proposed more than ten feminine stereotypes that often present in classic literature. However, not all of the stereotypes present in Guy de Maupassant's short stories; which means that some stereotypes may absent.
This research is applying an objective approach by Abrams that makes the analysis of the literary works focus on the work itself without taking into account the historical background of the stories, the biography of the author, or the relationship of the literary works with real life. The objective approach allows the analysis to be isolated from the external factors that correspond to the creation of literary works, and only focus on the intrinsic being of the short stories. (Abrams, 1971). It makes the analysis of the literature will remain focus on the literary works itself. Although literature cannot be separate from the real world, the mimetic approach to the work will not be unveiled, due to the limited purpose of this research to present the feminine stereotypes that appear in literary works

Literary works as a device to teach the reader about certain knowledge will also be discussed later. It will show how Guy the Maupassant trough his literary works not only tries to build his concept of women that correspond to the time he lived but also point out how his literary works are used to educate the reader about how a woman should behave ideally.

\section{Result}

Feminine stereotypes indeed present in 5 short stories by Guy de Maupassant that are chosen. The female characters are mostly described negatively trough the entire story. Although some characters are presented as ideal women at the beginning of the story, the final twist on the plot changes the entire perception toward the characters in 
which her entire image is ruined as the result of one single mistake.

Formlessness seems to be frequently used in 5 short stories in which the women's physical performance and mind are lack in so many ways that makes them fragile and unable to do serious things. Often, the women's brain is understood as deformed which caused them unable to be as knowledgeable than men. Physical formlessness on women related to a belief that women are not as fit as males while their mind is also liquid that makes them unable to think as complicated as men (Ellmann, 1979)

In order to create a formlessness nature on women, Guy de Maupassant in his The Kiss contrasting men and women by addressing the female character as 'Woman is gifted with charm, and she rules with caresses". while in other short stories A Family Affair, the female characters are described as fainting fits, thin, as well as someone who cant take care of themself. In The Umbrella the female character is described as little women to ensure that her physical appearance is less dominant than men. In his short story, Guy de Maupassant often describes women's physical appearance to be smaller and fragile than males. However, physical appearance is not the author's focus on creating the gap between men and women. Because in his short stories, Guy de Maupassant concentrates on maintaining the idea that women are minorities compared to males because of their inability to think logically.

Women are described as unstable creatures as their moods can change drastically and tend to be violence. At least there are three female characters that are believed to have violent tendencies, if not physical then verbal. Miss caravan in A Family Affair has assaulted others both verbal and physical as written "Madame Caravan attacked her sister-in-law, and the two women-the one with her enormous bulk, the other epileptic and spare, with changed voices and trembling hands flew at one another with words of abuse" while her mother in law is " always cross, and she never passed a day without quarreling and flying into furious tempers. She would apostrophize the neighbors... in the most violent language". both women in this short story directly address women's instability in which their mood is unpredictable and often leads to violence.

In The Umbrella, Mme. Oreille is also presented as unstable as she suddenly "screaming out in a transport of the most violent rage" after finding out a hole in her husband's umbrella. Her behavior in harassing people with harsh words and violent temper even makes her husband afraid of her. In this short story, dramatic changes are clearly presented. As the female character's calm mental state suddenly change into rage because of issue that is meaningless.

In other short stories, the changes in mood do not present as extreme as in both A Family Affair and The Umbrella, but there is a tendency in describing women who are easily emotional and cry when they don't get what they want as in The Diamond Necklace when the husband describes "He stopped, 
stunned, distressed to see his wife crying. Two large tears ran slowly from the corners of her eyes towards the corners of her mouth" which occur because his wife doesn't have dress and jewelry to go to the party.

While in Dead Women Secret, the nun express her emotion aggressively as written "And his sister, frantically striking her forehead against the woodwork, convulsed, twitching and trembling as in an epileptic fit, moaned". the instability of women in the stories often presents as inability to control their emotions. They are excessive when dealing with anger, upset, grief, and misery. While some male characters also presented to have emotional tendency but they are still under-control even when they have to deal with the death of their love one.

Not only women are unstable but they are also pictured as irrational, as they believe in illogical things as written in A Family Affair "Nobody but a woman would think of such a thing. It is not enough for them to worry you during life, but they cannot even leave you at peace when you are dead". As women feel that they must see the dead body of their neighbor before being buried. This action is considered irrational by male characters because the action is not based on sane logic as the author refers to this behavior as "queer fancy".

Materialism is another major stereotypes present in the short stories. Most of the female characters have a strong attraction to material things. As written in The Diamond Necklace that "She had no dresses, no jewels, nothing; and these were the only things she loved. She felt she was made for them alone". Her attraction to materials is not only limited to jewelry and fancy dresses to charm people. But she is also obsessed with fancy interior design and furniture for the houses.

Another female character in the story of A Family Affair also shares the same materialistic perspective. Madame Caravan was described as materialistic by the author as soon as she shows massive interest in his mother in law inheritance. As written "she was continually thinking of the inheritance". during the plot, Madam Caravan does not only justify that she deserves the inheritance but she also stole her mother properti

Unlike the female characters in The Diamond Necklace and A Family Affair, the main female characters in The Umbrella express her materialistic approach differently. Instead of asking for more, Mme. Oreille doesn't want to spend any money. She believes that "It is better to have too much than too little" which revers money. She is also deceitful in making the insurance company pay for the damage on the umbrella by giving a lie.

Although some male characters show interest in money and property they are not presented as extreme as the female characters who will do anything to get what they want. Men in the story tend to want money for good cause while women's attraction to money and luxurious things are presented as uncontrollable desire.

Women are also Passive, women passivity comes from a realization that women do not belong to anything as Guy de Maupassant state in his short story that "women don't belong to a caste or class". In the short stories, none 
of the female characters participate in social realm. Women are addressed as the wife of someone. The common name that is attached to the women characters is the name of their husband, their status in the family for example mother or addressing them based on their husband's job such as" hairdresser's wife" and "shopkeepers' wives". None of the female characters in the stories are presented as an active participant in the society, they are mostly described as full-time housewives who dedicate their lives to the family.

Due to their passivity image in the short stories, women are also confinement, in which they are unable to understand issues. There are many scenes in the short stories that promote women as someone who is unable to understand basic logic in life. In the story of The Diamond Necklace, the husband addressed his wife as "stupid" when she can't find the solution for simple matters. Women are also described as someone who cant understand logic as written in The Kiss that "they (women) persist in giving inopportune caresses, tire him by the obstinacy of begging lips and give caresses lavished with neither rhyme nor reason" which is later added by the author that the female character is "without seeing or understanding". It implies that women to respond to a situation accordingly, their confinement in understanding the situation may relate to their formlessness nature in which their mind is liquid. In addition, women are also regarded as careless and tasteless in short stories.

Hyper-sexuality on women also present in Guy de Maupassant's short stories. First, in his The Kiss as he wrote 'And you kept drawing out this torturing kiss, without seeing or understanding. Then when you freed him, you began to grumble: "How badly you kiss!" No wonder!". As Ellmann quote in her book that women are spiritual before the marriage but later they tend to be wild and demanding as she wrote it as "these women are malady by night. The nurse by day" (Ellmann, 1979).

In short story Dead Women Secret, the mother character is described to have a shocking truth behind her perfect and idealist lifestyle. She was remembered by her children as a strict mother who keeps morality "She had, from childhood up, armed them with a strict moral code, teaching them religion, without weakness, and duty, without compromise". however, the reality of her life seems to be far from perfect as she seems to have a love affair with a man when she is still married to her husband. As her affair exposed after her children read the letter from her lover "There was none, but only under the words, "The man who adores you," the name "Henry." Their father's name was Rene. Therefore this was not from him'. trough the beginning of the story, we believe that the mother is a saint person who is kind and held morality as a priority. However, her love affair with another man ruined her entire image; it is equivalent to Ellman concept where spirituality is premarital while hypersexuality comes after marriage. As women cannot control their desire as men, it leads to humiliation and affair. 
Piety is another stereotype of women that attach female characters in Guy de Maupassant's short stories especially Dead Women Secret. It attaches to the nun in which the author writes about her as "She, the girl, influenced by the virtue which had bathed her in this austere family, had become the bride of the Church through her loathing for man". it corresponds to what Ellmann believe as piety in female characters by male authors, in which they often describe as something to show but never felt (Ellmann, 1979). The nun is presented as a religious job but deep down she hates her hatred; it can also be implied that her religiosity is just a mask to the society.

\section{Discussion}

As it is previously discussed that feminine stereotypes also occur in classic short stories that are written by Guy de Maupassant. But the stereoscope of women itself is not only limited to the feminine stereotypes that are addressed by Marry Ellmann. In other shorts stories, the presence of feminine stereotypes can be varied and more specific to a certain race and social class. In fiction, we can find women represented as "enigmatic woman, estranged wife, as well as the prostitute" (Rosenmeier. 2011). and when the women characters are from another race they may be presented as inferior because they differ in terms of race, gender, and age (Vattoy. 2020).

Some researcher also tries to figure out whether the stereotypes of women also being practiced in real life. As they found that women are still being discriminated often being sexually harassed by their male colleagues (Carli, 2016). One of reason why stereotypes against women still present in today's life are because our private belief still relies on stereotypes association in rationalizing the world, it implicitly shaped our behavior in treating both genders unequally, it shapes how parents educate their children, how we choose our partner, as well as create our judgment about people based on their gender (Ellemers 2018). These stereotypes will remain in society as long as we still reintroduced the stereotypes through media consumption.

\section{- Men and women in apposition}

Guy de Maupassant is quite direct in addressing the distinctive nature and status of both male and female characters.as he wrote in his short story The Kiss "Man is gifted with physical strength, and he exercises force. Woman is gifted with charm, and she rules with caresses. It is our weapon, formidable and invincible". Guy de Maupassant sees men as superior in his short stories because they have both physical power and knowledge in which women lack in so many ways. Trough the same short stories, the author also noted the superiority of men by describing them as the center of knowledge as he adds later in his short stories that "history of man himself: Everything springs from it, the arts, great events, customs, wars, the overthrow of empires"

In the story The Diamond Necklace, Guy de Maupassant strengthens the ideas of women as marginal as he wrote "Women don't belong to a caste or class...make the daughters of 
commoners the equals of the very finest ladies". Distinguishing men and women through their role in literary works can be done through stereotyping, in which men and women share the opposite characteristic as women never be the center of society.

Unlike men who hold both physical power and knowledge, women are lack in many aspects. Women are described without capability to support themself, they are physically less powerful as being described as small, thin, and fragile compare to men who are strong and tall. In term of intelligence, women are not better than men as they cannot comprehend the basic logic, as the result they are often regarded as unintelligent, tasteless and confinement compare to men who are the source of all knowledge "history of man himself: Everything springs from it, the arts, great events, customs, wars, the overthrow of empire" (The Kiss). in addition, the author of the short stories directly stated in his work that men is the master of themself " while the man over whom we rule remains master of himself, capable of judging the foolishness of certain words" while women are always regarded as a wife of someone or as her status in the family such as Mother or Aunt. None of the women in these short stories became equally treated as human beings, as they always described as second class citizens who are always seen in negative perspectives.

Mary Ellmann stated in her book that "women tend to be not merely what men are not, but what the individual speaker is not, and even what he is not at any given moment" (1979). The female characters in the literature not only represent the opposite of men as both characters and author, which means that female stereotypes on literary works consist of ideology under patriarchy society. In the case of Guy de Maupassant's short stories, women are always less than men in terms of physical ability, social activity, and mental capacity in understanding the world. Women are seen as an incomplete person who is lack in many ways.

Guy de Maupassant not only takes men and women in opposition but he also uses other female characters to judge the main character in the story. The supporting female characters directly criticize the main female character if they are not becoming the opposite example of the main female character. In The Kiss, the Aunt wrote in her letter "my dear, I have several times noticed that you are very clumsy. However, you were not alone in that fault; the majority of women lose their authority by abusing the kiss with untimely kisses.'. In her letter, the Aunt clearly states her appointment's to the main female character for her inability to respond and to please her husband, in which later she advises her about how to deal with the same circumstance.

The Author in his short story also indicating the idea that negative behavior on women will pass down to their children as long as they are immediate relatives. A Family Affair, author wrote "Marie-Louise was already like her mother-spoke like her, repeated her words, and even imitated her movements" to strengthen the ideas 
that women's misbehavior can be passed down to their daughter. It also appears the same in short story Dead Women Secret in which the nun is presented as the exact copy of her mother in which both of them seems to look religious from the outside but wicked on their heart as the mother has an affair while married while the nun keeps hatred toward men.

Guy de Maupassant in his short stories not only marginalized women by attaching stereotypes image on the female characters, but he also suggests the behavior that should not be done by the female characters. Especially in his short story The Kiss, Guy de Maupassant directly list the types of misconduct on women that should be avoided at any case.

The fist misconduct that should be avoided by women as noted in The Kiss short story is "never kiss your husband in public" which implies that it is inappropriate to show your affection in public property. The result of this miss conduct is addressed by the author as ridiculous and feeling angry by your male partner. The second misbehavior that is addressed by the author is "Beware of useless kisses lavished in intimacy" which refers to the main character nature. She was mentioned by the Aunt that she have violated this rule that makes her husband left her.

Although the Aunt in The Kiss short story seems to only criticize the main character the purpose of the criticism is to addressed all women, as the author wrote that "the majority of women lose their authority by abusing the kiss with untimely kisses" in which later the author try to strengthen his ideas by adding "We all have this foolish habit, this unconscious need of choosing the most inconvenient moments". in this short story, "we" is addressed to other fellow women and not only limited to female characters that appear in this story. This means that the noticeable bits of advice from Aunt are actually implied by the Author by using Aunt character to deliver the issues to the readers.

\section{Literature as knowledge sharing media}

Literature as a special kind of writing can be used as an instrument to teach the reader certain ideas because literature contains discourse which is understood as material realities, social practices, and mental entities (Gee, 2001). it also means that literary works can be used to deliver the author ideas to readers. Although literature is mostly enjoyed as art we can't avoid the fact that literature also contains knowledge that can be used as reference (Köppe and Langkau. 2018). While reading literary works makes knowledge transfer possible whether direct, indirect, or reverse (Azagra-Caro, Fernández-Mesa, and Robinson-García. 2020)

As literature has knowledge contained in it, we cannot avoid the fact that it also presents women stereotypes to build the story. However, Stereotypes in nature are a general expectation in which one is overemphasized while the other is underestimate (Ellemers 2018). Often some of them are far from reality and subjective that makes some of the stereotypes unreliable.

The presence of feminine stereotypes has its own purposes. However, Guy de Maupassant in his five short stories uses feminine stereotypes to build separate 
space between women and men as well as to correct the problems within the society in which most of them caused by the female characters in his short stories in which he often described as detestable.

Stereotypes are often created to targeting women who do not cooperate with traditional forms of male-female interdependence: resenting women who violate prescriptive gender roles by competing with men at work, by being sexually controlling, or by rejecting intimate heterosexual relationships... In contrast with women who cooperate with traditional male-female interdependence; they adhere to prescriptive gender roles by remaining subordinate to men at work, by being sexually subservient to male requirements, or by embracing prescriptive heterosexual relationships (Fiske. 2017). as they are presented in Guy de Maupassant as women who have violated the norm will be punished by society. The first short story The Kiss in which a wive is humiliated her husband ends up being left. In The Diamond Necklace, the women have to pay severely for losing the jewelry as the result of their materialistic nature. In the Dead Women Secret, the mother is lo longer respected by their children after they unveil her love affair. In The Umbrella, the women also being humiliated by the officer for being too stingy, while in A Family

\section{Bibliography}

Abrams, M. H. (1971). The mirror and the lamp: Romantic theory and the critical
Affairs the main female characters are unable to retrieve the inheritance she wants. Almost all female characters in Guy De Maupassant's short stories who are described as detestable with unkind behavior will end up being punished for what they lack. And trough his literary works, Guy de Maupassant tries to deliver these ideas to the readers, giving criticism, advice, and humiliation to the female characters in order to strengthen the ideas that their behavior is not acceptable within the society.

Trough giving advice and criticism, Guy de Maupassant used his literary works as media to teach the reader about how women should behave within the community. The short story contains his discourse about women, he tries to maintain the minority of women by describing them as second class citizens with feminine stereotypes. By addressing the same stereotypes over and over in his literary works, the negative concept of women in his short story will remain in his readers unconsciously. It seems acceptable to see Guy de Maupassant's short stories as his device in spreading the patriarchy discourse to maintain women's position as a minority and second citizens.

tradition (Vol. 360). New York: Oxford University Press

Azagra-Caro, J. M., Fernández-Mesa, A., \& Robinson-García, N. (2020). 'Getting out of the closet': scientific authorship of literary fiction and 
knowledge transfer. The Journal of Technology Transfer, 45(1), 56-85.

Carli, L. L., Alawa, L., Lee, Y., Zhao, B., \& Kim, E. (2016). Stereotypes about gender and science: Women $\neq$ scientists. Psychology of Women Quarterly, 40(2), 244-260.

De Maupassant, G. (2013). The Entire Original Maupassant Short. Simon and Schuster

Ellemers, N. (2018). Gender stereotypes. Annual review of psychology, 69, 275-298.

Ellmann, M. (1979). Thinking About Women. 1968. London: Virago, 7.

Fiske, S. T. (2017). Prejudices in cultural contexts: shared stereotypes (gender, age) versus variable stereotypes (race, ethnicity, religion). Perspectives on psychological science, 12(5), 791-799

Kathlyn and Gay Hendricks. (2012, April 22nd). Woman: Person or Property. Huffpost. Retrived August $4^{\text {th }} \quad 2020$. from https://www.huffpost.com/entry/ woman-person-or-property-

b_1282620

Kautzmann, L. N. (1992). Using literature to educate students: images of caregivers in poetry and prose. Educational Gerontology: An International Quarterly, 18(1), 17-26.

Köppe, T., \& Langkau, J. (2018). Fiction, Self-Knowledge and Knowledge of the Self.

Rosenmeier, C. (2011). Women stereotypes in Shi Zhecun's short stories. Modern China, 37(1), 44-68

Sugino, T. (1998). Gender stereotypes and children's literature. The Language Teacher, 22(6), 112-120.

Trombetta, Sadie. (2016, March 31st). 9 Books About Women's Rights You
Should Read. Retrived August $4^{\text {th }}$ 2020.

from

https://www.bustle.com/articles/1

50884-9-essential-books-aboutwomens-rights-you-should-read-

before-national-womens-historymonth-is-over

Vattöy, S. (2020). Oppression of black women in The Bluest Eye: The interplay of race, gender and age.

Zirker, A. (2010). " The road to happiness": Jane Austen's Mansfield Park. Connotations: a Journal for Critical Debate, 20(2/3), 131 



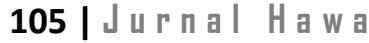

